\title{
Learning Through A Scientific Approach From The Philosophy Of Progressivism
}

\author{
$1^{\text {st }}$ Monika Agnes H. $\mathrm{K}^{1}\left({ }^{凶}\right), 2^{\text {nd }}$ Laila Fitriana ${ }^{2}$ \\ ${ }^{1,2}$ Postgraduate of Mathematics Education, Faculty of Teacher Training and Education, Universitas Sebelas Maret, Surakarta, \\ Indonesia \\ Corresponding author. Email: monikaagnes9edstudent.uns.ac.id
}

Accepted: Mey 25,2021

Approved: June 30, 2021

Published: July 25, 2021

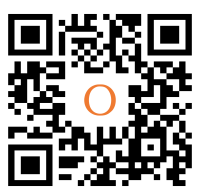

DOI
Abstract-The purpose of this article is to describe the learning of mathematics through a scientific approach reviewed from the philosophical school of progressivism. Reference data comes from research results including books and journal articles that are relevant to the topic. The results showed that the school of progressivism is a school in the philosophy of education that requires a change in the positive direction in education. The scientific approach includes five steps: (1) observing, (2) questioning, (3) collecting, (4) associating and (5) communicating. The conclusion of this article is that the scientific approach is in line with the philosophy of progressivism because it requires learning centered on learners.

Keywords - Progressivism, Saintific Approach, Mathematics

Publisher: El Syits Project

\section{INTRODUCTION}

In this era of globalization, education in Indonesia is one of the fields that continuously improves its quality to compete with education in other countries. A country that has quality education reflects an advanced and modern society, because through good education, one has optimal attitudes, knowledge, and skills. Education has an important role, so education must be designed and implemented carefully. Education in globalization era is very important, so it needs to be developed in a more advanced direction by looking at the various abilities possessed by humans. So, it is important to develop human creativity so that education is recommended, namely learning with student-centered, where educators as a companion to the development of student potential. In fact, teachers often guide the procedure from start to finish, so learning is increasingly passive because students only accept the transfer of knowledge. Windschitl (1) suggests that students do not construct based on understanding of their ideas, but the student's job is to understand, apply and reconstruct the teacher's thinking. Related to these issues, there needs to be a change in education in order to further advance and develop.

The philosophy of progressivism is a school in the philosophy of education that requires change or progress in the implementation of education. This school opposes educator-centered learning, it focuses education on learners, and require learners to always explore their abilities in preparation for everyday problems. The flow of progressivism is one of the foundations in developing the curriculum implemented in Indonesia today, namely curriculum 2013. The 2013 curriculum is defined as a curriculum developed to improve and balance soft skills and hard skills in the form of attitudes, skills, and knowledge (2).

The learning approach in the 2013 curriculum that is relevant to the school of progressivism is one of them is the scientific approach. The scientific approach is designed so that students can actively construct and explore a concept and principle through the stage of observing, formulating problems, formulating hypotheses, collecting data, and communicating the principle that has been found (3). So, it can be concluded that the 2013 Curriculum is very in accordance with the philosophy of progressivism.

The writing of this article aims to explain the learning process with a scientific approach from the perspective of progressivism. The discussion is focused on the process of learning mathematics based on the perspective of progressivism using theoretical studies and appropriate literature materials. 


\section{RESEARCH METHOD}

The writing of this article uses library research methods. Data collection comes from research results including books and journal articles that the author considers relevant to the topic then analyzed. The author examines the references contained in the literature so as to provide information about the role of scientific approaches in learning reviewed the perspective of progressivism

\section{RESULTS AND DISCUSSIONS}

\section{PHILOSOPHY OF PROGRESSIVISM}

Progressivism is derived from the word "progressive" which means moving forward. Progressivism is one of the philosophical schools that wants an advance that will lead to a modification towards a better direction. Muhmidayeli (4) defines progressivism as a school that wants rapid progress. In line with this opinion, Gutek (5) states that humans have the potential to develop and perfect their environment by applying their intelligence with the scientific method to solve problems that arise in human life itself as well as social life.

The school of progressivism was first popularized by William James and John Dewey, focusing on aspects of practical life benefits. Progressivism has an open nature, has a high curiosity, and always investigates for the sake of gaining experience (6). Based on this, the school of progressivism requires the potential of a person in solving problems by associating the experiences possessed by each individual. Progressivism education requires a change in students to be resilient and able to face problems using creative thinking.

\section{LEARNING IN VIEW OF PRogRESSIVISM}

Progressivism is flexible, which is perfect for advancing education. This means that the school of progressivism is very open in seeing a person's ability to solve problems through experience. Education according to John Dewey is leading to the flexibility of learners, so that the potential includes creativity in solving a problem. Thus, the success of education can be seen from the extent to which education is able to develop various potential students optimally. The philosophy of progressivism has a distinction between the position of educators and learners in the learning process. The nature of progressivism learning requires learning oriented to activities centered on students, so that the task of educators as facilitators, supervisors, and directors for students. Educators also play a role in encouraging students to be able to argue, plan and solve their problems. Radu, L (7) concludes that learning based on progressivism is primarily in the interest of learners, so that, it can solve a problem.

\section{SCIENTIFIC APPROACH}

Scientific approaches can be used in learning mechanisms to process changes that result in progress based on the principle of progressivism. The scientific approach is defined as a method of gaining knowledge with stages based on the scientific method. The scientific approach of the 2013 curriculum includes 5 steps: (1) Observing, (2) Questioning, (3) Collecting information, (4) Processing information, and (5) Communicating. These five steps of activities are designed in order to develop students' creativity and curiosity as well as to improve the understanding of student concepts. Scientific learning has characteristics, namely: 1) Focusing on learners, 2) Containing skills in constructing learning concepts, 3) Involving potential cognitive processes, and 4) Developing learners' ethics in learning (8). In the scientific approach, students themselves build new knowledge by connecting previous material. The series of stages of scientific approaches to mathematical learning is believed to be able to improve cognitive ability of learners, in accordance with the results of research Rahmawati et al (9) which successfully improved the ability of mathematical connections through a scientific approach to trigonometric materials.

\section{Learning Use of SCIENTIfiC APproaches in the Philosophical Perspective of Progressivism}

Progressivism is bold and open. The philosophical school of progressivism considers that the process of moving forward is based on the human ability to develop science. This pattern of thinking is in accordance with the scientific approach, where students float their knowledge based on their experience. Presents several educational principles emphasized in the school of progressivism, namely: 1) the educational process begins and ends in students; 2) the subject of the student is active, not passive; 3 ) the role of the teacher is only as a facilitator, guide or director; 4) the school must be cooperative and democratic; 5) activity is more focused on problem solving, not teaching of studying materials.

As a facilitator or guide, teachers play a role in helping students to express and communicate ideas from the results of investigations obtained individually and in groups. One of the mathematical materials of SMP is a system of twovariable linear equations. To explore the problem of the two-variable linear equation system, teachers can provide a 
Ordinal: Innovation in Research, Development, and Learning on Mathematics Education Journal Doi:

stimulus in the form of a problem so that students can be observed. "Lisa and Andrew bought two types of candles. Lisa spent Rp35,300.00 to buy three purple candles and five white candles. While Andrew paid Rp16,200.00 to buy two purple candles and two white candles. How much does each candle cost?" It is expected to encourage students to have curiosity so as to raise some questions.

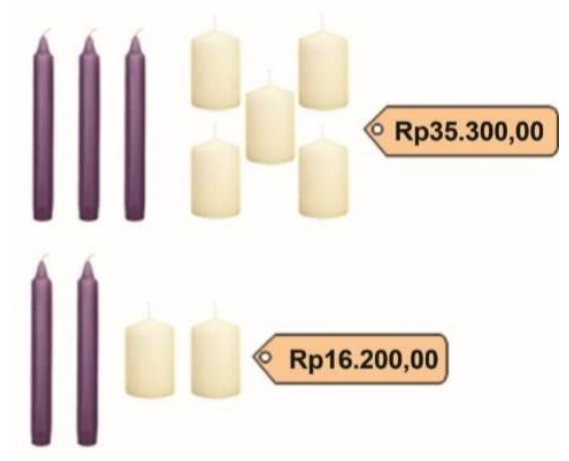

Fig. 1. Figure 1. Question of SPLDV

After providing a stimulus, students can be given a student worksheet to collect information about the two-variable linear equation system and then process it. With the student worksheet, it is expected that students can create an equation model, as well as be able to determine the price of one purple candle and the price of one white candle. After gathering information, the teacher encourages students to communicate, in which case exposing the results of the findings either orally or with other media. Through activities to associate the concept of SPLDV with daily experiences, it is expected to minimize misconceptions and encourage students to be more interested in communicating their ideas.

\section{CONCLUSIONS AND SUGGESTIONS}

The philosophy of progressivism is a school that requires positive change in the implementation of education. It opposes the existence of traditional learning and student-centered learning. Progressivism is one of the foundations in developing the curriculum implemented in Indonesia today, namely curriculum 2013. Scientific approaches is relevant to the school of progressivism. The scientific approach to the 2013 curriculum includes 5 stages, namely observing, assessing, gathering information, processing information and communicating. A series of stages of scientific approaches to learning mathematics is believed to be able to improve the cognitive abilities of learners, because students themselves can build new knowledge by associating previous materials..

\section{REFERENCES}

[1] Windschitl, M. (2006). Sparking the debate over science education reform. Education Digest: Essential Readings Condensed for Quick Review, 71(8). 20-31.

[2] Fadillah, M. 2014. Implementasi Kurikulum 2013 dalam Pembelajaran SD/MI, SMP/MTS dan SMA/MA. Yogyakarta: ArRuzz Media

[3] Maryani. (2020). Pengaruh Pendekatan Saintifik Dalam Proses Belajar Mengajar Siswa Kelas VIII Materi Lingkaran. Jurnal Derivat, 7 (2), 65-74.

[4] Muhmidayeli, M. (2011). Filsafat pendidikan. Bandung: Refika Aditama Undang-Undang No. 20. 2003. Sistem Pendidikan Nasional. Jakarta.

[5] Gutek. Gerad Lee. (1974). Philosofical alternatives in education. Loyala University of Chicago.

[6] Djumransjah. (2002). Filsafat Pendidikan. Jawa Timur: Bayumedia Publishing

[7] Radu, L. 2011. John Dewey and Progressivism in American Education. Bulletin of the Transilvania University of Brasov, 4(2). 85-90

[8] Habidah, M. (2020). Pengembangan E-Modul Berbasis Pendekatan Saintifik pada Mata Pelajaran Marketing Kompetensi Dasar Menganalisis Segmentasi Pasar di Kelas X SMK Negeri 1 Jombang. Jurnal Pendidikan Tata Niaga (JPTN). 972-978.

[9] Rahmawati, Y., Priatna, N. \& Nurjanah. 2018. Meningkatkan Kemampuan Koneksi Matematis dan Self Concept Siswa Melalui Pendekatan Saintifik Pada Materi Trigonometri. Jurnal Matematika dan Pendidikan Matematika, 3(2). $108-122$. 
Monika Agnes H. K \& Laila Fitriana, Learning Through A Scientific ...

\section{AUTHORS}

$\mathbf{1}^{\text {st }}$ Monika Agnes H. K is a Postgraduate of Mathematics Education, Faculty of Teacher Training and Education, Universitas Sebelas Maret, Surakarta, Indonesia, (monikaagnes9e@ @student.uns.ac.id)

$2^{\text {nd }}$ Laila Fitriana is Postgraduate of Mathematics Education, Faculty of Teacher Training and Education, Universitas Sebelas Maret, Surakarta, Indonesia, (lailafitriana_fkip@staff.uns.ac.id) 